\title{
Characterization of a new mutation (R292G) and a deletion at the human uroporphyrinogen decarboxylase locus in two patients with hepatoerythropoietic porphyria
}

\author{
Hubert de Verneuil ${ }^{1,2 *}$, Francine Bourgeois ${ }^{1,2}$, Felix de Rooij ${ }^{3}$, Peter D.Siersema ${ }^{3}$, J.H.P.Wilson ${ }^{3}$, \\ Bernard Grandchamp ${ }^{1,2}$, and Yves Nordmann ${ }^{1.2}$ \\ ${ }^{1}$ Laboratoire de Génétique Moléculaire, Faculté Xavier Bichat, 16, Rue Henri Huchard, F-75018 Paris, France \\ ${ }^{2}$ Laboratoire de Biochimie, Hôpital Louis Mourier, 178, Rue des Renouillers, F-92701 Colombes Cédex, France \\ ${ }^{3}$ Department of Internal Medicine II, University Hospital Dijkzigt, NL-3015 GD Rotterdam, The Netherlands
}

Received October 1, $1991 /$ Revised December 2, 1991

Summary. A deficiency in the activity of uroporphyrinogen decarboxylase (UROD), the fifth enzyme of the haem biosynthetic pathway, is found in familial porphyria cutanea tarda (F-PCT) and hepatoerythropoietic porphyria (HEP). A new mutation (R292G) and a deletion have been found in a pedigree with two HEP patients (two sisters). The R292G mutation was not detected in 13 unrelated affected patients with F-PCT, so it appears to be uncommon. The possibility that the arginine 292 may participate at the active site of the enzyme is discussed. A summary of the 7 mutations/deletions found in the UROD gene with their frequency is presented.

\section{Introduction}

Hepatoerythropoietic porphyria (HEP) is a rare homozygous form of familial porphyria cutanea tarda (F-PCT) that occurs early in infancy (for a review, see Kappas et al. 1988). The characteristic enzyme deficiency is a profound decrease in the activity of uroporphyrinogen decarboxylase (UROD), the fifth enzyme of the haem biosynthetic pathway (Elder et al. 1981; Lazaro et al. 1984), whereas the enzyme activity in F-PCT is about $50 \%$ of the normal level (Kushner et al. 1976; de Verneuil et al. 1978). Evidence for heterogeneity in inherited UROD deficiency has been well documented at the protein level with CRIM (cross-reactive immunological material)positive (presence of an abnormal immunologically detectable protein) and CRIM-negative (absence of the abnormal protein) cases (Sassa et al. 1983; de Verneuil et al. 1984, 1986b; Toback et al. 1987; Fujita et al. 1987; Koszo et al. 1990).

We have characterized the first mutation $(\mathrm{G} 281 \mathrm{E})$ in one of the CRIM-negative family leading to a protein

* Present address and address for correspondence: Département de Biochimie et Biologie Moléculaire, Université Bordeaux II, 146, Rue Léo Saignat, F-33076 Bordeaux Cédex, France that is very rapidly degraded in the presence of cell lysate (de Verneuil et al. 1986a). Another point mutation (E167K, Romana et al. 1991) has been recently described in another HEP patient. Three different mutations have been described in F-PCT. Interestingly, one mutation occurs at the same position as the HEP G281E mutation, but involves the substitution of a Val rather than a Glu (Garey et al. 1989). Two splice site mutations in the UROD gene have also been described in F-PCT (Garey et al. 1990).

In this paper, we describe the characterization of a new mutation and a deletion in two HEP patients from the same family.

\section{Materials and methods}

\section{Cases studied}

The patients consisted of two sisters (patients I and II) with HEP from non-consanguineous parents of Caucasian origin (Holland) (Fig. 1). Neither parent had experienced any clinical symptoms of the disease. Diagnosis of HEP was confirmed by enzymatic studies. UROD was measured on haemoglobin-free haemolysate

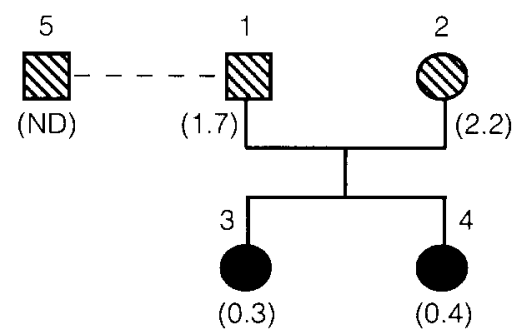

Fig. 1. Family pedigree with results from enzymatic studies. Both parents ( 1 mother; 2 father) are clinically unaffected. The children (3 patient I; 4 patient II) have clinical symptoms of porphyria and a porphyrin excretion pattern characteristic of HEP. Individual 5 is a second degree relative of the father. Numbers in parentheses are UROD activities (normal values $4.8 \pm 1.2 \mathrm{U} / \mathrm{mg}$ of protein; $N D$ not done) 
with pentacarboxylic porphyrinogen I as substrate (de Verneuil et al. 1983). One unit of UROD activity is defined as the amount of enzyme preparation that catalyzes the formation of $1 \mathrm{nmol}$ coproporphyrinogen $\mathrm{I}$ per $\mathrm{h}$ at $37^{\circ} \mathrm{C}$ in the standard assay medium. Results were as follows: father, 1.7 unit per mg of protein; mother, 2.2 ; patient $\mathrm{I}, 0.4$; patient $\mathrm{II}, 0.3$; normal values, $4.8 \pm 1.2$ (2 standard deviations).

\section{In vitro amplification}

RNA was isolated from lymphocytes by non-ionic detergent lysis (Sambrook et al. 1989). Reverse transcription sequences of cDNA were amplified in vitro in a mixture of $50 \mu \mathrm{l}$ containing $70 \mathrm{mmol} / \mathrm{l}$ TRIS-HCL at $\mathrm{pH} 8.8,1.5 \mathrm{mmol} / / \mathrm{MgCl}_{2}, 0.1 \%$ Triton $\mathrm{X}-100$, $200 \mu$ mol each of dATP, dCTP, dGTP, dTTP, 20 pmoles of each primer (UDE 11:5'-CCGGAATTCAGTTACAGACAGCTGACC-3' and UDE 61: 5' -TGTGTTAGTGGTACTTGAGGGTA3 ) and 1 unit of Taq polymerase (Gibco BRL). The cDNA was denatured for $3 \mathrm{~min}$ at $95^{\circ} \mathrm{C}$ and amplified for 30 cycles $(1 \mathrm{~min}$ at $94^{\circ} \mathrm{C}, 1 \mathrm{~min}$ at $55^{\circ} \mathrm{C}, 1 \mathrm{~min} 30 \mathrm{~s}$ at $70^{\circ} \mathrm{C}$ ) in a DNA Thermal Cycler (Perkin-Elmer).

DNA was extracted from blood by the usual methods. A sample of $200 \mathrm{ng}$ of DNA was amplified in vitro in a mixture of $50 \mu \mathrm{l}$ containing $70 \mathrm{mmol} / 1$ TRIS-HCL at $\mathrm{pH} 8.8,1.5 \mathrm{mmol} / 1 \mathrm{MgCl}_{2}$, $0.1 \%$ Triton X-100, $200 \mu$ mol each of dATP, dCTP, dGTP, dTTP, 20 pmoles of each primer (UDI 70:5'-GCAAGGCCCTCTGTAGCCTGA-3' and UDE 62:5'-GTCCTGGAAACGATCAATC$\left.3^{\prime}\right)$ and 1 unit of $T a q$ polymerase (Gibco BRL). Conditions were identical to those used for the cDNA amplification.

\section{cDNA cloning and sequencing}

The polymerase chain reaction (PCR) products were subcloned into the pGEM7Zf + vector (Promega Biotec, Madison, WI). The DNA was purified by gel filtration on an S-200 column (Pharmacia, Sweden) and subcloned into an EcoRI-HindIII-digested vector. Different independent clones were then sequenced by the dideoxychain termination method (Sequenase sequencing kit, USB Corporation)

\section{Oligonucleotide hybridization analysis}

Amplified fragments were slot-blotted onto a nylon membrane and then hybridized to allele-specific oligonucleotides (ASOs). The sequence of the two ASOs are as follows: 292N: 5'. AGAAAGCCCGGTAAGCC-3' and 292M: 5'-AGAAAGCCGGGTAAGCC- $3^{\prime}$. Probe labelling, hybridization $\left(56^{\circ} \mathrm{C}\right)$ and posthybridization filter washes $\left(58^{\circ} \mathrm{C}\right)$ were carried out according to the method described previously (Grandchamp et al. 1989), except that oligonucleotides and temperatures were varied as mentioned above.

\section{In vitro degradation studies}

RNA was made by transcribing cDNA in vitro using T7 RNA polymerase after linearization of the plasmid with HindIII. The RNA was then translated in vitro in a micrococcal nuclease-treated rabbit reticulocyte lysate in the presence of $\left[{ }^{35} \mathrm{~S}\right]$ methionine (de Verneuil et al. 1986b). Aliquots $(5 \mu \mathrm{l})$ of the translation mixture were incubated at $37^{\circ} \mathrm{C}$ for $0,24,48$ and $80 \mathrm{~h}$ in the presence of $15 \mu \mathrm{l}$ sonicated lymphoblastoid cell lysate $(2 \mathrm{mg} / \mathrm{ml})$. Translation products were analysed by SDS (sodium dodecylsulphate) polyacrylamide gel (10\%) electrophoresis.

\section{Results}

The two primers used for the cDNA-PCR allowed the amplification of the cDNA sequence corresponding to
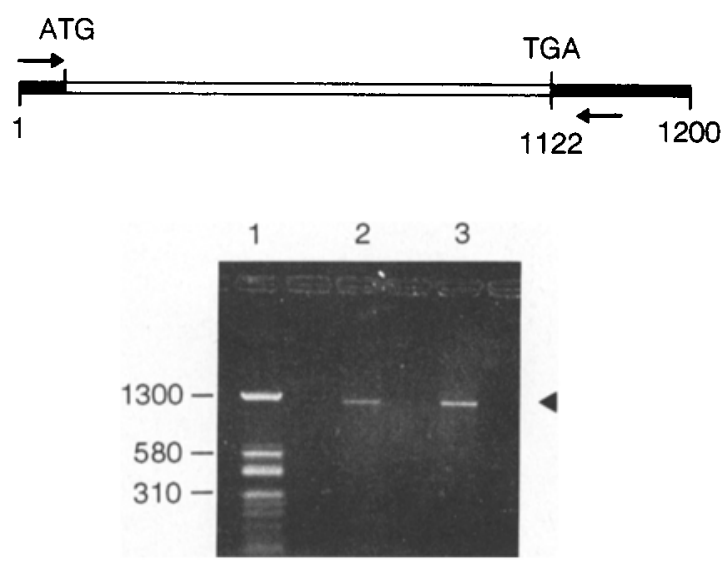

Fig. 2. Amplification of the UROD cDNA by PCR. Upper part schematic drawing of the $\mathrm{CDNA}$ with the two primers UDE11 and UDE62 used for the amplification. Lower part PCR amplification products of cDNA derived from lymphocytes of a normal individual (lane 3) and of patient I (lane 2). Arrowhead indicates the position of the amplified fragment (1165 bp)

A

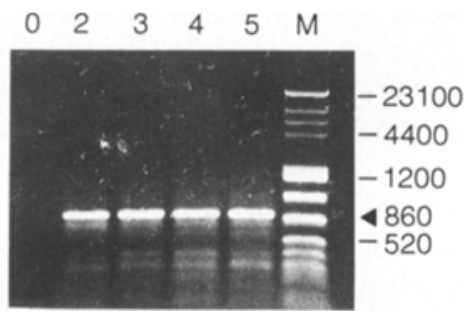

B

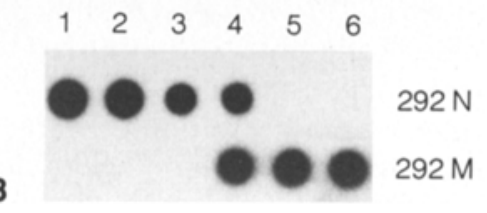

Fig. 3A, B. Characterization of the R292G mutation at the genomic level. A PCR amplification products of genomic DNA using the two primers UDI70 (in intron 7) and UDE62 (exon 10). Lanes 2-5 correspond to the amplification of genomic DNA from a control, the father, the mother and patient I. Lane 0 no DNA added to the amplification mixture. B Dot-blots of the amplified fragments with the normal $(292 \mathrm{~N})$ and the mutant $(292 \mathrm{M})$ oligonucleotides. Lane 1 amplified DNA from a relative of the father; lane 6 amplified DNA from patient II. Other lanes show amplified DNAs identical to those in the same lanes in $\mathbf{A}$. The sequences of the two ASOs are as follows: 292N , 5'-AGAAAGCCCGGTAAGCC-3'; 292M, 5'-AGAAAGCCGGGTAAGCC-3'

the entire coding region of the protein (see Fig. 2, upper part). Amplified fragments of identical size were obtained both with patient I and control cDNAs (Fig. 2, lower part). Hybridization with ASOs corresponding to the 3 previously known point mutations (G281E, de Verneuil et al. 1986a; G281V, Garey et al. 1989; E167K, Romana et al. 1991) revealed no hybridization (data not shown), leading to the conclusion that these patients carry (an)other mutation(s).

Cloning and sequencing of the amplified fragment from patient $I$ revealed that two independent clones carry a $\mathrm{C}$ to $\mathrm{G}$ change at nucleotide 892 , leading to a $\mathrm{Arg}$ $292 \rightarrow$ Gly substitution (R292G) in the protein. No other 

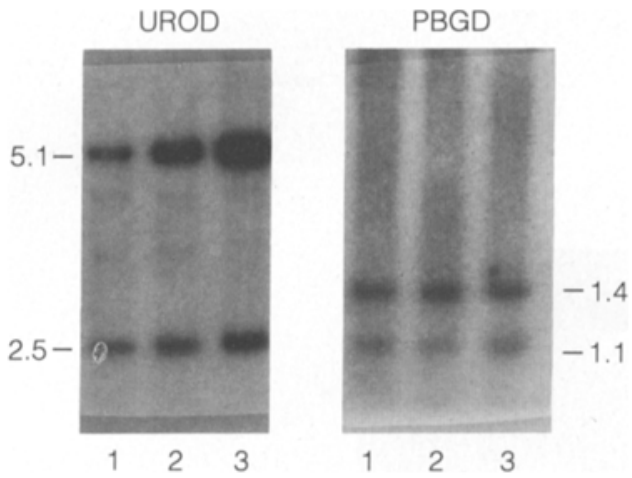

Fig. 4. Blot hybridization of human genomic DNA. DNA $(7 \mu \mathrm{g})$ was digested with $P_{s t} 1$ and electrophoresed in a $1 \%$ agarose gel. The DNA was denatured, transferred to a nylon membrane (Hybond- $\mathrm{N}^{+}$, Amersham) and hybridized with either $\left.{ }^{32} \mathrm{P}\right]$ UROD cDNA or porphobilinogen deaminase (PBGD) cDNA probes. Lanes 1-3 DNA from the father, the mother and a control, respectively

base change was found. We confirmed that this nucleotide substitution suppresses a SmaI site (5'-CCCGGG-3') in the cDNA by direct digestion of the PCR-amplified products with $S m a I$ (data not shown). This restriction site (position 890-895 on the cDNA; see Romeo et al. 1986 for the normal human sequence) corresponds to the exon 8-intron 8 boundary (Romana et al. 1987a) and is not conserved in the genomic DNA. We therefore decided to confirm the mutation at the gene level by hybridization of an amplified genomic DNA fragment of 860 bp (from intron 7 to exon 10) with ASOs (Fig. 3). The normal oligonucleotide probe ( $292 \mathrm{~N}$ ) hybridized to DNA from normal controls. The mutant probe (292 M) hybridized to amplified DNA from the patient, whereas no signal was found with the normal oligonucleotide, confirming the existence of the mutation at the genomic level.

At this point of the study, two hypotheses could have explained the results: either patient I is homozygous for the R292G mutation or she is heterozygous for this mutation and carries a deletion of the UROD gene. A family study was then undertaken to clarify this point. Amplified genomic fragment from the mother hybridized with both probes $(292 \mathrm{~N}$ and $292 \mathrm{M})$ ), confirming that she carries the R292G mutation. In contrast, the amplified fragment from the father hybridized only with the normal probe: this result indicates that the father carries a deletion that is not detectable by our PCR amplification. We then performed a Southern blot analysis in order to characterize the deletion of the UROD gene (Fig. 4). We could not find any fragments of an abnormal size from the DNA of the father with three different restriction enzymes (EcoRI, HindIII, PstI). However, a weaker signal was found for the specific fragment from the father compared with the mother, or a normal control, confirming the existence of a deleterious allele from the father.

In vitro translated $\left[{ }^{35} \mathrm{~S}\right]$-labelled normal and mutant UROD proteins were exposed to lymphoblastoid cell lysates (for $0 \mathrm{~h}, 24 \mathrm{~h}, 48 \mathrm{~h}$ and $80 \mathrm{~h}$ ) and then subjected to electrophoresis on polyacrylamide SDS gels. No signifi-

\begin{tabular}{|c|c|c|c|}
\hline Mutations & Original description & $\begin{array}{l}\text { Frequency } \\
\text { in HEP }\end{array}$ & $\begin{array}{l}\text { Frequency } \\
\text { in F-PCT }\end{array}$ \\
\hline Gly281 $\rightarrow$ Glu & $\begin{array}{c}\text { HEP } \\
\text { Verneuil et al. } 1986\end{array}$ & $8 / 14$ & $0 / 20$ \\
\hline Glu $167 \rightarrow$ Lys & $\begin{array}{c}\text { HEP } \\
\text { Romana et al. } 1991\end{array}$ & $2 / 14$ & $0 / 15$ \\
\hline Arg292 $\rightarrow$ Gly & $\begin{array}{c}\text { HEP } \\
\text { This paper }\end{array}$ & $1 / 14$ & $0 / 13$ \\
\hline Large deletion & $\begin{array}{c}\text { HEP } \\
\text { This paper }\end{array}$ & $1 / 14$ & - \\
\hline Gly $281 \rightarrow$ Val & $\begin{array}{c}\text { F-PCT } \\
\text { Garey et al. } 1989\end{array}$ & $0 / 14$ & $1 / 20$ \\
\hline Exon 6 deletion & $\begin{array}{c}\text { F-PCT } \\
\text { Garey et al. } 1990\end{array}$ & $0 / 14$ & $4 / 20$ \\
\hline Exon 6 deletion & $\begin{array}{c}\text { F-PCT } \\
\text { Garey et al. } 1989\end{array}$ & $0 / 14$ & $1 / 20$ \\
\hline
\end{tabular}

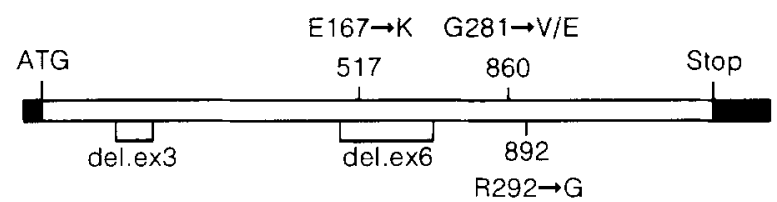

Fig. 5. Summary of the different mutations/deletions found in the UROD gene with their frequency. The lower part represents a schematic drawing of the cDNA with the position of the initiating codon ATG (nucleotides 19-21) and the STOP codon TGA (nucleotides 1120-1122). Numbers along the figure give the position of the mutations on the cDNA. The position of the two exon deletions are also shown. E $167 \rightarrow \mathrm{K}:$ Glu167 $\rightarrow$ Lys mutation; G281 $\rightarrow$ V/E: Gly $281 \rightarrow$ Val and Gly $281 \rightarrow$ Glu mutations: R292 $\rightarrow$ G: Arg292 $\rightarrow$ Gly mutation. The upper part of the figure gives the list of the different mutations/deletions found in HEP and F-PCT, and the frequency of each mutation/deletion (two mutated alleles for the HEP patients, one mutated allele for the F-PCT patients)

cant difference in degradation between the normal and the mutant protein was found.

We checked for the presence of the R292G mutation in 13 unrelated F-PCT patients by hybridization of specific genomic fragments with the ASOs. None of the 13 tested patients carries the mutation.

Figure 5 is a summary of the different mutations/deletions found in the UROD gene in HEP and F-PCT. The frequency of the mutations has been calculated from seven HEP patients from 7 unrelated families (14 mutated alleles) and from 13-20 F-PCT patients (13-20 mutated alleles). This frequency is not accurate because of the small number of families (the disease is very rare) and because of possible consanguinity. However, we can conclude from these results that a great heterogeneity exists among the mutations responsible for HEP or F-PCT in humans. Two different mutations (the G281E mutation for HEP and a splice site mutation that causes the deletion of exon 6 in F-PCT) appear to be more common.

\section{Discussion}

The present study describes a molecular analysis of the UROD gene in two new HEP patients. The strategy that 
1 rUROD MEANGLGLQNFPELKNDTFLRAATGEETDYTPVWSMRQAGRYLPEFRETR $\frac{1}{2}$ hUROD MEANGLGPQGFPELKNDTFLRAAWGEETDYTPVWSMRQAGRYLPEFRETR 50

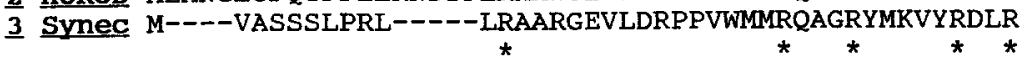

1 AA-QDFFSTCRSPEACCELTVQPLRRFPLDAAIIFSDILVVPQALAMEVTMVPGKG

2 AA-QDFFSTCRSPEACCELTLQPLRRFPLDAAIIFSDILVVPQALGMEVTMVPSKG 105

3 DKYPGFRERSETPELAIEISLQPFRAFKPDGVILFSDI *

1 PSFPEPLREERDLEALRDPAAVASELGYVFQAITLTRRRLAGRVPLIGFAGAPWTL 2 PSFPEPLREEQDLEALRDPEVVASELGYVFQAITLTRQRLAGRVPLIGFAGAPWTL 161

1 MTYMVEGGSFKTMAQAKRWLYQKPVASHKLLGILTHALVPYLIGQVAAGAQALQLF 2 MTYMVEGGGSSTMAQAKRWLYQRPQASHQLLRILTDALVPYLVGQVVAGAQALQLF 217

1 ESHAGHLGSELFSKFALPY IRDVAKRVKAGLQKAGLTRMPMI IFAKDGHFALEELA 2 ESHAGHLGPQLFNKFALPYIRDVAKQVKARLREAGLAPVPMIIFAKDGHFALEELA 273

1 QAGYEVVGLDWTVAPKKARECVGKTVTLQGELDPCALYASEEEIGRLVQQMLNDFG 2 QAGYEVVGLDWTVAPKKARECVGKTVTLQGNLDPCALYASEEEIGQLVKQMLDDFG 329 reav

1 PQRYIANLGHGLYPDMDPEHVGAFLDAVHKHSRLLRQN

2 PHRYIANLGHGLYPDMDPEHVGAFVDAVHKHSRLLRQN 367
Fig. 6. Amino acid sequence alignment of rat (lane 1), human (lane 2) and bacterial (lane 3; from Kiel et al. 1990) enzymes. The one-letter code is used. The numbers to the right of the sequence indicate the position of the residue relative to the $\mathrm{N}$-terminal methionine (position 1 ) of the human enzyme. The conserved arginines $(R)$ are indicated by stars and the mutated (292) arginine is underlined. The position of the two previously determined 167 and 281 mutations is also underlined. The four residues (lane 4) correspond to the yeast sequence (R. Labbe-Bois, personal communication), Dashes represent gaps introduced to maximize the homology we used is as follows: extraction of total RNA from the lymphocytes of one of the patients allowed us to amplify in vitro the entire coding sequence in a single step of PCR. Because of the presence of amplified fragments that were normal in size, we have been able to determine that a point mutation ( $R 292 \mathrm{G}$ ) is present in the patient. This mutation has been confirmed at the DNA level by specific amplification of a part of the gene (from intron 7 to exon 10) and by hybridization with ASOs. A familial study revealed that the $\mathrm{R} 292 \mathrm{G}$ mutation is present in the DNA of patient II and the mother, but not the father. Illegitimacy was excluded by a study of restriction fragment length polymorphisms of the HLADQ locus in the family. Because amplified DNA from both children did not hybridize with the normal $292 \mathrm{~N}$ probe, the only explanation of the profound deficiency present in both children and the $50 \%$ deficiency present in the father's blood is a deletion of the UROD gene on one allele. Southern blot analysis did not detect any abnormally sized UROD gene fragments, leading to the conclusion that the deletion is large, at least more than $3 \mathrm{~kb}$ (corresponding to the size of the UROD gene explored by the cDNA probe). Chromosome walking from the $5^{\prime}$ end and 3 ' end of the gene will be needed to characterize the deletion further.

The mutation results in the presence, in the abnormal protein, of a glycine residue instead of an arginine. Interestingly, this arginine is a conserved amino acid in the rat (Romana et al. 1987b) and in yeast proteins (R. Labbe-Bois, personal communication) (Fig. 6). Kinetic data of crude or purified normal human, chicken and bovine UROD suggest that there may be between 2 and 4 active sites for the different sequential decarboxylations of uroporphyrinogen to coproporphyrinogen (de Verneuil et al. 1980, 1983; Kawanishi et al. 1983; Straka and Kushner 1983). Experiments using SH-inactivating agents suggest that at least one cysteine is involved in the decarboxylation (de Verneuil et al. 1983). It is probable that basic amino acids are also involved in the catalytic site or are important for the integrity of the protein, because of the high conservation of these residues (Fig. 6). Chemical modification of cationic residues present in different enzymes of the haem pathway results in the rapid inactivation of the protein. This has been demonstrated for ferrochelatase (Dailey and Fleming 1986) and uroporphyrinogen III synthase (Hart et al. 1985) for arginyl residues, and for porphobilinogen deaminase (Miller et al. 1989) and aminolevulinate dehydratase (Gibbs and Jordan 1986) for lysyl residues. These considerations raise the possibility that the arginine 292 may participate at the active site of the enzyme by the formation of ionic bonds with the different acetic and/or propionic side chains of the substrate uroporphyrinogen. Isolation of normal and mutated proteins from over-expressing strains should allow us to study the three dimensional structure of the protein and to determine the different residues involved in the active site(s).

Acknowledgements. We thank Professor Jacques Elion for the HLADQ haplotyping of the family, and Dr. Pavel Martasek for critical reading of the manuscript.

\section{References}

Dailey HA, Fleming JE (1986) The role of arginyl residues in porphyring binding to ferrochelatase. J Biol Chem 261:7902-7905

Elder GH, Smith SG, Herrero C, Lecha M, Mascaro JM, Muniesca AM, Czornecki DB, Brenau J, Poulos V, De Salamanca RE (1981) Hepatoerythropoietic porphyria: a new uroporphyrinogen decarboxylase defect or homozygous porphyria cutanea tarda? Lancet I:916-919

Fujita H, Sassa S, Toback AC, Kappas A (1987) Immunochemical study of uroporphyrinogen decarboxylase in a patient with mild hepatoerythropoietic porphyria. J Clin Invest $79: 1533$ 1537 
Garey JR, Hansen JL, Harrison LM, Kennedy JB, Kushner JP (1989) A point mutation in the coding region of uroporphyrinogen decarboxylase associated with familial porphyria cutanea tarda. Blood $73: 892-895$

Garey JR, Harrison LM, Franklin KF, Metcalf KM, Radisky ES, Kushner JP (1990) Uroporphyrinogen decarboxylase: a splice site mutation causes the deletion of exon 6 in multiple families with porphyria cutanea tarda. J Clin Invest 86:1416-1422

Gibbs PNB, Jordan PM (1986) Identification of lysine at the active site of human 5-aminolevulinate dehydratase. Biochem J 236: $447-451$

Grandchamp B, Picat C, Rooij F de, Beaumont C, Wilson P, Deybach JC, Nordmann Y (1989) A point mutation G-A in exon 12 of the porphobilinogen deaminase gene results in exon skipping and is responsible for acute intermittent porphyria. Nucleic Acids Res 17:6637-6642

Hart GJ, Battersby AR (1985) Purification and properties of uroporphyrinogen III synthase from Englena gracilis. Biochem $\mathbf{J}$ 232: $151-160$

Kappas A, Sassa S, Galbraith RA, Nordmann Y (1988) The porphyrias. In: Stanbury JB (ed) The metabolic basis of inherited disease. McGraw-Hill, New York, pp 1305-1365

Kawanishi S, Keki Y, Sano S (1983) Uroporphyrinogen decarboxylase: purification, properties and inhibition by polychlorinated biphenyl isomers. J Biol Chem 258:4285-4292

Kiel JA, Boels JM, Beldman G, Venema G (1990) Nucleotide sequence of the Synechococcus sp. PCC7942 branching enzyme gene: expression in Bacillus subtilis. Gene 89:77-84

Koszo F, Elder GH, Roberts A, Simon N (1990) Uroporphyrinogen decarboxylase deficiency in hepatoerythropoietic porphyria: further evidence for genetic heterogeneity. Br J Dermatol $122: 365-370$

Kushner JP, Barbuto AJ, Lee GR (1976) An inherited enzymatic defect in porphyria cutanea tarda. J Clin Invest 58: 1089-1097

Lazaro P, De Salamanca RE, Elder GH, Villaseca ML, Schinarro S, Jaqueti G (1984) Is hepatoerythropoietic porphyria a homozygous form of porphyria cutanea tarda? Br J Dermatol 110: 613-617

Miller AD, Packman LC, Hart GJ, Alefounder PR, Abell C, Battersby AR (1989) Evidence that pyridoxal phosphate modification of lysine residues (Lys-55 and Lys-59) causes inactivation of hydroxymethylbilane synthase (porphobilinogen deaminase). Biochem J 262:119-124

Romana M, Dubart A, Beaupain D, Chabret C, Goossens M, Romeo PH (1987a) Structure of the gene for human uroporphyrinogen decarboxylase. Nucleic Acids Res 15:7343-7356

Romana M, Le Boulch P, Romeo PH (1987b) Rat uroporphyrinogen decarboxylase cDNA: nucleotide sequence and compari- son to human uroporphyrinogen decarboxylase. Nucleic Acids Res $15: 7211$

Romana M, Grandchamp B, Dubart A, Amselem S, Chabret C. Nordmann Y, Goossens M, Romeo PH (1991) Identification of a new mutation responsible for hepatoerythropoietic porphyria. Eur J Clin Invest 21:225-229

Romeo PH, Raich N, Dubart A, Beaupain D, Pryor M, Kushner J, Cohen-Solal M. Goossens M (1986) Molecular cloning and nucleotide sequence of a complete human uroporphyrinogen decarboxylase cDNA. J Biol Chem 261:9825-9831

Sambrook J, Fritsch EF, Maniatis T (1989) Molecular cloning: a laboratory manual, 2nd edn. Cold Spring Harbor Laboratory, Cold Spring Harbor, NY

Sassa S, Verneuil H de, Anderson KE, Kappas A (1983) Purification and properties of human erythrocyte uroporphyrinogen decarboxylase: immunological demonstration of the enzyme defect in porphyria cutanea tarda. Trans Assoc Am Physicians $96: 65-75$

Straka JG, Kushner JM (1983) Purification and characterization of bovine hepatic uroporphyrinogen decarboxylase. Biochemistry $22: 4664-4672$

Toback AC, Sassa S, Poh-Fitzpatrick MB, Schecter J, Saider E, Harber LC, Kappas A (1987) Hepatoerythropoietic porphyria: clinical, biochemical and enzymatic studies in a three generation family lineage. N Engl J Med 316:645-647

Verneuil H de, Aitken G, Nordmann Y (1978) Familial and sporadic porphyria cutanea tarda: two different diseases. Hum Genet 44:145-151

Verneuil H de, Grandchamp B, Nordmann Y (1980) Some kinetic properties of human red cell uroporphyrinogen decarboxylase. Biochim Biophys Acta 611:174-186

Verneuil H de, Sassa S, Kappas A (1983) Purification and properties of uroporphyrinogen decarboxylase from human erythrocytes. J Biol Chem 258:2454-2460

Verneuil H de, Beaumont C, Deybach JC, Nordmann Y, Sfar Z, Kastally R (1984) Enzymatic and immunologic studies of uroporphyrinogen decarboxylase in familial porphyria cutanea tarda and hepatoerythropoietic porphyria. Am J Hum Genet $36: 613-622$

Verneuil H de, Grandchamp B, Beaumont C, Picat C, Nordmann Y (1986a) Uroporphyrinogen decarboxylase structural mutant (Gly281Glu) in a case of porphyria. Science 234:732-734

Verneuil H de, Beaumont C, Grandchamp B. Phung N, Nordmann Y (1986b) Molecular heterogeneity of uroporphyrinogen decarboxylase deficiency in hepatoerythropoietic porphyria. In: Nordmann Y (ed) Porphyrins and porphyrias. John Libbey Eurotext, Paris, pp 201-208 